\title{
The Mexican debt crisis redux: international interbank markets and financial crisis, I977-I982
}

\author{
SEBASTIAN ALVAREZ \\ University of Geneva
}

\begin{abstract}
The international banking crisis that began in 2007 has brought the relationship between international banking activities and financial crises to the forefront. The growing reliance on foreign interbank funding by domestic banks has been recognized as a crucial factor in explaining the banking and sovereign debt crisis currently affecting several peripheral European countries. This article shows that the link between financial crisis and international interbank lending is not a new phenomenon; a similar trend can be observed in the Mexican banking sector during the run-up to its 1982 debt crisis. I explore the international activities of Mexican commercial banks in the years preceding the country's default and demonstrate that they became involved in international lending which was funded largely through heavy short-term interbank foreign borrowing. I provide new archival evidence which shows that in intermediating foreign finance with local public and private borrowers, Mexican banks incurred maturity, interest rate and currency mismatches and dangerously increased their risk position. This article provides insights for understanding the Mexican debt crisis as closely intertwined with problems in the domestic banking sector, which were, in turn, linked to its involvement in the international financial system.
\end{abstract}

Keywords: sovereign debt, financial crisis, Euromarkets, Latin America

JEL classification: $\mathrm{H}_{63}, \mathrm{~N} 26, \mathrm{~N} 86$

S. Alvarez, The Paul Bairoch Institute of Economic History, University of Geneva, 40, bd du Pontd'Arve, I2 I I Geneva 4, Switzerland; email address: sebastian.alvarez@unige.ch; personal webpage: www.sites.google.com/site/salvarezo6/. I am especially grateful to Mary O'Sullivan and Juan H. Flores for guidance, encouragement and support. The paper has benefited greatly from comments and suggestions from Jérôme Sgard, Gail Triner, Stefano Battilossi, Eugene White and two anonymous referees. I thank Sergio Negrete Cárdenas, Gustavo del Angel and Ricardo Solís for helpful discussions and references, as well as Carlos Tello, Angel Gurría, Lee Buchheit and William Rhodes for sharing their insightful experiences. I am also indebted to archivists at the Federal Reserve Bank of New York, the International Monetary Fund and the Banks for International Settlement for their support. Last, I would like to thank participants at seminars and workshops at New York University, Rutgers University, El Colegio de Mexico and University of Geneva for comments, as well as Richard Sylla for the kind invitation to stay at Stern NYU during the 20I3/20I4 academic year, which made this study possible. Financial support from the Swiss National Sciences Foundation (SNSF) is gratefully acknowledged (Grant No. PIGEPI_I48536). 


\section{I}

The global banking meltdown that began in August 2007 has led to a growing body of research on the relationship between banks' international activities and financial crises. While some of these studies have focused on the role of foreign off-balance sheet exposures in the banking sector, scholars have also highlighted the vulnerability to crisis created by banks' wholesale external borrowing in the international interbank market. Specifically, researchers have argued that a growing reliance by banks in certain countries on short-term cross-border funding (Fender and McGuire 20I0; Merk Martel, Van Rixtel and Gonzalez Mota 2012), along with currency and maturity imbalances between their assets and liabilities (CGFS 20I0), made their national banking sectors dangerously vulnerable to shifts in US money markets and international interbank lending.

Indeed, discussions concerning international interbank markets have moved into the spotlight during the current European crises. Since the intensification of the financial crisis in the second half of 2008 , Euro area banks have been confronted with major dislocations in international wholesale markets and have consequentially experienced severe funding strains (Caruana and Van Rixtel 20 I 3; Van Rixtel and Gasperini 20I 3 ). The heightened dependence of domestic banks on foreign interbank funding has been recognized as a primary factor in explaining the vulnerability of certain banking sectors, such as Ireland and Iceland, to the crisis (Honohan et al. 20Io; SIC 20IO). As for other troubled peripheral countries, such as Spain and Greece, problems in the banking sector have become increasingly intertwined with sovereign debt crises, which have put further pressures on banks, both in terms of access to funding and its cost (Shambaugh 20I2; CGFS 20II).

Most of this research assumes, at least implicitly, that the growth in international interbank funding is a recent phenomenon. ${ }^{1}$ Symptomatic of this lack of historical perspective is the fact that the Bank for International Settlements (BIS), the institution responsible for much of the recent research, was centrally involved in a similar episode during the run-up to the I 980 international debt crisis. In I982, the BIS established a study group on the international interbank market, which reported that up to threequarters of the international lending boom that had taken place in previous years consisted of interbank positions. ${ }^{2}$ There is reason to think, therefore, that there was an important link between bank's wholesale foreign activities and the financial crisis of the I980s, in what had threatened to be the largest international banking meltdown since the Great Depression.

This article focuses on the link between foreign interbank market operations and financial crisis in Mexico, beginning in 1977 up to the outbreak of the debt crisis in I982. Mexico is a valuable case study to address these issues. First, Mexico was not only one of the biggest international debtors, but also the country whose

\footnotetext{
1 See, for instance, graphs 4 and 5 in Caruana and Van Rixtel (2013, pp. 7-8).

2 BIS Archives, box I/3A(3)M vol. I. See also BIS (I983, pp. I7-I9).
} 
moratorium in August 1982 triggered the international debt crisis and put the whole global banking and financial system on the brink of collapse. ${ }^{3}$ Second, the country's leading banking institutions were actively involved in foreign finance, becoming both major borrowers and lenders in the international capital markets. Finally, there are good reasons to assume that the experience of Mexico can be also found in other Latin American countries, such as Brazil and Argentina, whose governments and financial institutions followed similar footsteps and also suffered from serious financial crises. ${ }^{4}$

During the lead-up to the debt crisis, when considerable amounts of foreign finance flowed into Mexico, leading domestic commercial banks became highly involved in intermediating foreign finance with domestic final borrowers (Quijano I987, pp. 24I-58). However, despite the importance of their international borrowing and lending activities, neither the literature on Mexico's external debt nor the research on the sovereign debt crisis and its debt renegotiation process have given much attention to the role of the domestic banking sector. ${ }^{5}$ This article shows how Mexican commercial banks were crucially entangled in the country's external indebtedness process through the channelling of international wholesale liquidity back home, and that in doing so, they dangerously increased their risk position.

Until now, international interbank markets and developing countries' commercial banks have been largely absent in the extensive literature on the debt crisis of the I980s. ${ }^{6}$ In this article, I reconstruct the essential elements of the international business model of Mexican banks by drawing on a variety of archival sources that have recently become available. I show how, through their branches and associated banks overseas, Mexican commercial banks raised large amounts of foreign capital in the US and British international interbank markets, which they used to relend either directly, or through off-shore centres, to public and private borrowers at home. I provide new evidence which shows that in running their international activities, they accumulated serious maturity, interest rate and (indirect) currency mismatches on their balance sheets. My account is largely based on Federal Reserve Bank of New York archives and from forms that Mexican banks in the US were required to file with the Federal Financial Institutions Examinations Council (FFIEC), known as FFIEC 002 Report Forms. ${ }^{7}$ I also draw on reports and historical statistics from the Banco de Mexico as well as documents and records from archives of the IMF and the BIS.

3 Boughton (200I), in particular, pp. 28I-3I7.

4 See Altimir and Devlin (I994), Devlin and Ffrench-Davis (I995), Diaz-Alejandro (I984), and Sachs and Williamson (I985).

5 Main references on the subject are Dornbusch (I990), Green (I988, I998), Kraft (I984), Marichal (20 I I), Negrete Cárdenas (forthcoming), Solís and Zedillo (I985), and Zedillo (I985).

6 See, for instance, Cline (I984, I995) and Devlin (I989), three of the most influential works on the international debt crisis of the I980s.

7 Report of Assets and Liabilities of US Branches and Agencies of Foreign Banks (FFIEC 002). 
In the run-up to the crisis, a number of events contributed to a worsening of banks' financial mismatches and led to a deterioration of their financial position. The sharp increase in international interest rates during the late I970s and early I980s exacerbated the interest rate mismatch between the banks' liabilities that had been contracted at floating rates and their foreign loans, which had been largely arranged at predetermined interest rates. At the international level, moreover, beginning in mid I98I, a general retrenchment in the US interbank market endangered Mexican banks' single most important source of foreign funding. The FebruaryMarch 1982 devaluation made it more difficult for large private Mexican companies to reimburse their dollar debt to domestic banks and for Mexican banks, in turn, to service their foreign creditors. Finally, the Mexican government's moratorium declaration in August 1982 gave the coup de grace to Mexican banks' wholesale foreign borrowing.

Although overlooked in the literature, Mexican banks' interbank foreign liabilities played a key role during the renegotiations and in the stabilization programmes. Mexico's negotiators, along with its official international creditors, sought to have creditor banks maintain access to interbank credit lines to Mexican banks. After the nationalization of the Mexican banking sector, and as part of the first rescheduling programme for Mexican debt, an agreement was reached to freeze interbank deposits with the foreign branches and agencies of Mexican banks at the August 1982 premoratorium levels. This agreement would be extended in subsequent rescheduling agreements. The outstanding interbank loans would remain frozen for almost ten years, until a definitive market-oriented solution was finally proposed in I99 I, as part of the banks re-privatization programme.

The rest of the article is organized as follows. Section II presents evidence showing the extent that Mexican commercial banks relied on foreign interbank borrowing to fund their international loans prior to I982. Section III describes the business model and the economic rationale behind their foreign activities. In Section IV, I analyse the rising fragility of the Mexican banking system, including the exposures and imbalances incurred by large international banks. Sections V and VI explore the financial difficulties banks faced in the run-up to the crisis, as well as the solution finally adopted to secure their interbank funding needs. Based on the analysis of of the experience in Mexico, in the last section, I draw overreaching conclusions linking international activities of banks to financial crisis during the I980s. Avenues for future research on the topic are highlighted.

In the decade-long run-up to the I982 crisis, Mexico experienced the most notable growth of its external debt in the history of the country (Marichal 2000; Solís and Zedillo I985). Mexicans' ability to borrow in foreign capital markets reflected a broader enthusiasm among international creditors in providing financing to developing economies during the I970s. Following the oil shock of I973, the petrodollar 
recycling process flourishing in the Euromarkets eventually led to an international lending boom to the developing world, where Mexico, along with other Latin American economies, attracted the lion's share (Devlin I989). At that time, Latin American economies were undertaking final stages of the import-substituting industrialization (ISI) process and foreign capital was a major piece of the funding strategy (Bértola and Ocampo 20I2). In Mexico, as in other Latin American countries suffering from credit booms followed by financial crises and busts in the early I980s, foreign borrowing was partly intermediated by the domestic banking system. ${ }^{8}$

Between I977 and I982, when substantial amounts of capital flowed into Mexico, the commercial banking sector significantly increased its foreign liabilities. While the external debt of the Mexican public sectors increased by one and a half times during that period, commercial banks' foreign indebtedness more than tripled. ${ }^{9}$ Indeed, the rise of banks' external debt is even more striking when considered in terms of their balance sheets. According to Banco de Mexico's annual reports, obligations to the external sector passed from representing only 3.I per cent of the total liabilities of the commercial banking sector in I 977 to 20.2 per cent in I982: a bit less than a sevenfold increase in five years. These foreign liabilities essentially consisted of loans from international banks - in particular interbank facilities - operating in main international financial centres. ${ }^{10}$ Such figures give a clear sense of the extent and the intensity of commercial banks' borrowing in the international capital markets during the years preceding the crisis. ${ }^{11}$

The rise in banks' foreign liabilities coincided with an improvement of their lending capacities. Total financing provided by the commercial banking sector rose from US\$ I 2.6 billion in I 977 to US\$ 46 billion at the beginning of I982, expanding at the rate of 38 per cent per on average. Interestingly, dollar financing was the more dynamic component, with the dollar loan portfolio increasing by 5.5 times compared to loans in pesos, which more than tripled during the same time period. Banks' higher dollar lending capacities relied, to a large extent, on the foreign currencies that they were able to borrow on international capital markets. Intermediation of foreign capital with Mexican borrowers was mainly made through syndicated Eurocredits, but also by direct lending from London and other main international financial centres.

8 See Sundararajan and Baliño (I99I) and Mendoza and Terrones (2008) for a review on credit booms and financial crises during the I970s and the I980s in Latin America.

9 Based on data from Negrete Cárdenas (I999) and Solís and Zedillo (I985).

10 Banco de Mexico's annual report of I978 details the composition of commercial banks' obligation with the external sector, which reached US\$ 620 in I977 and US\$823 in I978 and consisted entirely of all loans from foreign banks (pp. Io9-Io).

11 At that time, the Mexican banking system was made up by commercial banks, state-owned development banks and Banco de Mexico. For a description of the Mexican banking system and its place within the financial system as well as the interaction and network relationship with the rest of the financial actors see del Angel (2002), in particular, chapters 4 and 5 as well as appendix I and 2. A broader characterization of the Mexican financial system during those years can be found in Solís (I997). 
Syndicated deals were brought to London and promoted by a large international commercial bank, usually from the US or another developed country, under a mandate granted by the borrower. Once there, the leading bank formed a lending syndicate with other banks and worked together to provide funds. Although largely dominated by banks from industrialized countries, Mexican commercial banks actively took part in these operations. According to Quijano (I987, pp. 244-7), of the US\$ I 6 billion raised by the 322 Eurocredits granted to Mexico between I970 and I979, US\$ 5. I billion, or 32 per cent, included participation by Mexican commercial banks, both as leaders or as associated syndicate members. Banamex and Bancomer, the two largest Mexican commercial banks, along with their London-based consortium banks, the International Mexican Bank (Intermex) and the Libra Bank, accounted for the vast majority of these operations. Indeed, as shown in Negrete Cárdenas (I999), in terms of the number of Eurocredits granted to the Mexican public sector between I973 and I982, these banks ranked among major foreign lenders such as Bank of America, Chase Manhattan and Citibank. ${ }^{12}$

Mexican commercial banks gained a foothold in the major international financial centres during the I970s. They first arrived in London through the creation of consortium banks in joint ventures with other international banks from developed and developing countries. The Libra Bank, founded in I972, along with Intermex and the Euro-Latinamerican Bank (Eulabank), both established in 1974, were the three consortium banks with Mexican ownership. ${ }^{13}$ The 1974 Mexican banking reforms empowered domestic banks to participate in the capital stock of foreign financial institutions and to open agencies and branches abroad. ${ }^{14}$ In effect, in addition to their involvement in London-based consortium banks, late in the decade, leading Mexican commercial banks would eventually establish their own international offices. By I982, the six largest commercial banks Bancomer, Banamex, Banca Serfin, Multibanco Comermex, Banco Mexicano-Somex and Banca Internacional, which represented up to three-quarters of the commercial banking market share in Mexico, were running their own branches and agencies in the main international financial centres, with London and New York as their primary destinations. ${ }^{15}$

The internationalization of Mexican banking took place in a context of financial and banking deregulation. During the mid I970s, Mexico, along with other Latin American countries with highly repressed financial systems, introduced a number of reforms that attempted to liberate the financial sector. Kaminsky and Schmukler

12 Intermex was the largest Mexican lender. It participated in 24 Eurocredits and ranked fifth among the leaders in bank-syndicated loans to Mexico between 1973 and 1982 (Negrete Cárdenas I999, table B.I7, p. 400).

13 They were owned by Bancomer, Banamex and Banca Serfin with 8,38 and $6 \%$ of the shares respectively.

14 See Borja Martínez (I978, pp. 43 I-2).

15 There were in total 2 I foreign branches and agencies of Mexican commercial banks in six foreign cities: Bancomer, Banamex and Serfin with four offices each, Comermex with five and Somex and Banca Internacional with two each (CIEN-Ai3/E-68/Agosto de I982). 
(2003) found that between I973 and I974, both capital account controls and regulations on the domestic financial system were relaxed in Mexico. As far as commercial banks were concerned, financial private institutions were now allowed to engage in offshore borrowing and to issue certificates of deposit at market-determined interest rates. Deregulation continued in the following years, through reductions and unification of the reserve requirement, softening interest rate controls, and increases on dollar borrowing and lending limits. The introduction of multi-purpose banking of I975, which replaced the former restricted regime of specialized banking with a universal banking system, was a step forward. The reform lifted regulations that had previously pushed specialized financial institutions to operate in a single financial market and provided banks with greater flexibility in their intermediation activities. ${ }^{16}$ As a result of these reforms, between I977 and I982, the Mexican banking sector increased its participation in the Mexican economy and recovered from a seven-year trend toward financial disintermediation. ${ }^{17}$

During the I970s, Mexican banks created consortium banks and set up overseas offices, in large part, to involve themselves in Euromarkets and engage in Eurocurrency businesses. Their presence in London and New York allowed the banks to access the two biggest international interbank markets and open a dollarbased funding channel. The fact that the vast majority of commercial banks' foreign offices were branches or agencies, as opposed to subsidiaries, reveals that their parent banks were not interested in developing regular retail banking businesses in the host country, which would have required bank subsidiary status. ${ }^{18}$ As agencies or branches, these banks were forbidden from taking conventional direct deposits. The focus was thus on wholesale banking instruments, like federal funds and interbank credit lines, which were available in the marketplace.

Most of the funding to meet the demand for international loans by Mexican banks came from the international interbank market. As Paul Mentre emphasized in a report for the Institute of International Finance, it was by accessing the interbank market that 'LDC commercial banks typically borrowed on the US domestic market or on the London dollar market to relend directly, or through offshore centres, to final borrowers'. ${ }^{19}$ In practice, interbank markets acted as channels from banks with a domestic

16 For an explanation of the multi-bank reform and the implications for the Mexican banking and financial system see del Angel (2002) and Seijas Román (I99I).

17 The Total Assets/GDP ratio for private banks in I97I, I977 and I982 was 35, 26 and 42\% respectively (del Angel 2006, p. 637).

18 Branches were not technically defined as banks, so there was an important difference in terms of regulation. Since they were not legally separate from their parent banks, they were not separately capitalized and were primarily supervised by their home authorities. As such, they were not subject to the host country's reserve requirements.

19 Mentre (I985, p. 4). 
dollar base or an excess of deposits towards banks where direct lending exceeded deposits. Such was the situation of Mexican and LDC's banks overseas, since as Phillip Wellons observed '[their] function [was] to act as a go-between for domestic borrowers, including their home office, and to raise money ... in world markets for their home countries'. ${ }^{20}$

The business model of consortium banks relied, to a large extent, on interbank market deposits as a source of funds. While interbank loans normally accounted for one-fifth of the banks' assets, on the liabilities side, interbank placements ranged from 40 per cent of the banks' total liabilities, up to Ioo per cent in a certain number of cases. ${ }^{21}$ Thus, by borrowing more than they lent to other banks, these banks were usually net takers of funds within the international interbank market. Mexican commercial banks also conformed to the same net borrowing pattern, and, as explained by Banamex Director José Manuel Rivero, the modus operandi consisted in 'making placements with [creditor banks], for example, placing \$Io million with an institution that is providing $\$ 20$ million to Banamex'. ${ }^{22}$ In the same vein, Serge Bellanger, vice-president of the Institute of Foreign Bankers and Crédit Industriel et Commercial's New York branch manager, pointed out that when examining the liabilities side of foreign banks in general, the 'interbank borrowings from the domestic and Eurodollar markets still remain a major component of the funding strategy'.23

This business pattern can be illustrated by examining the case of the agencies and branches of Mexican banks in the US. As of June I982, total combined assets and liabilities of the six bank agencies in New York and four in Los Angeles reached US\$2.9I billion. Figure I provides the composition of the agencies' assets and liabilities at a consolidated level. On the liability side, the breakdown shows that borrowed money was their main fundraising instrument, followed by federal funds and deposits and credit balances. Taken together, they accounted for US $\$ 2.35$ billion or 80.7 per cent of total liabilities. The fact that only US\$ I0.9 million or 0.5 percent of this amount was due to creditors other than banks highlights the prominent role of financial institutions as virtually the only suppliers of funds for Mexican agencies. The remaining 562 million (or I9 per cent) of agencies' total liabilities, basically consisted of transfers from their head offices in Mexico and bankers' acceptances. These figures give a clear sense of the large extent that their funding relied on the interbank market.

On the assets side, loans were agencies' most important claims, accounting for US\$ I.9 billion or 65.4 per cent of the total. They consisted of direct or purchase loans that were mainly granted to commercial and industrial (public or private) enterprises (73.9 per cent), and, to a lesser extent, to other financial institutions (I 5.4 per cent) and to foreign governments (9.6 per cent). Agencies' second largest asset was net transfers to

\footnotetext{
20 Wellons (i977, p. 77).

21 See Davis (I980) and Dufey and Giddy (I994).

22 FRBNY Archives, Central Files, file BAC I983.

23 'The foreign challenge to US banks', The Banker, October I978, p. 40.
} 

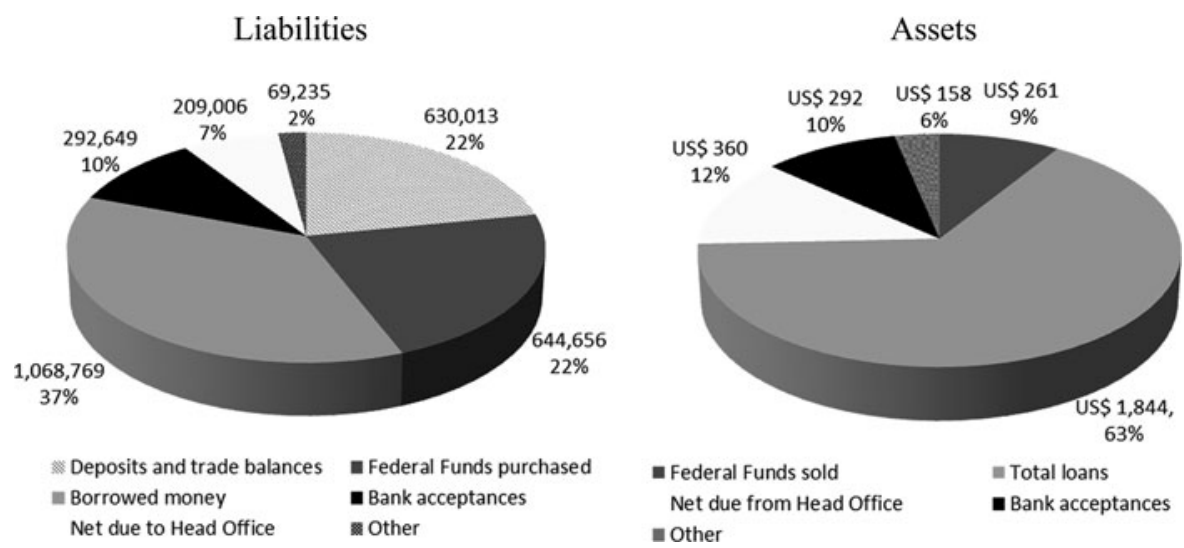

Figure I. Total combined assets and liabilities of US agencies and branches of Mexican banks by instrument, June 1982

Source: FFIEC 002 Reports.

their head offices, followed by bankers' acceptances and Federal Funds sold to US banks. Overall, an estimated 80-90 per cent of the US agencies total assets represented claims on Mexican borrowers, and about 60 per cent represented loans to the Mexican government or the public sector. ${ }^{24}$ This asset and liability composition makes the business model clear: borrow from commercial banks in the US interbank money market and lend to final users in Mexico. As extensions of their parent banks, foreign agencies channelled US money to Mexico and managed the liquid dollar assets of their international networks.

The significance of the foreign agencies of Mexican banks lay not only in their international business, but in the fact that they became the main door to international wholesale liquidity. As stressed by the BIS Study Group on interbank markets, although creditor banks seemed to have regularly lent to other banks in London or to banks of similar standing in other major financial centres or offshore centres, cross-border transactions with banks operating in remote financial centres raised more concerns. ${ }^{25}$ Data from Banco de Mexico Annual Reports show that by the end of 198I, borrowing from foreign banks had provided commercial banks with US $\$ 6.5$ billion, of which as much as 70 per cent had been raised by foreign agencies while the remaining 30 per cent were loans directly granted to the head offices in Mexico. $^{26}$

${ }^{24}$ FRBNY Archives, Central Files, file C26I - Mexican Government I9I7-84.

25 See BIS (I983), p. 35 .

${ }^{26}$ It is worth mentioning that as foreign banks were not allowed to open branches or agencies in Mexico (Citibank being the only exception), these cross-border interbank transactions represented foreign liabilities of Mexican banks and not inter-offices business of foreign banks. For an account of the presence of foreign banks in Mexico, see del Angel (2002, pp. I39-48), and Sánchez Aguilar (I973) for the particular case of US banks. 


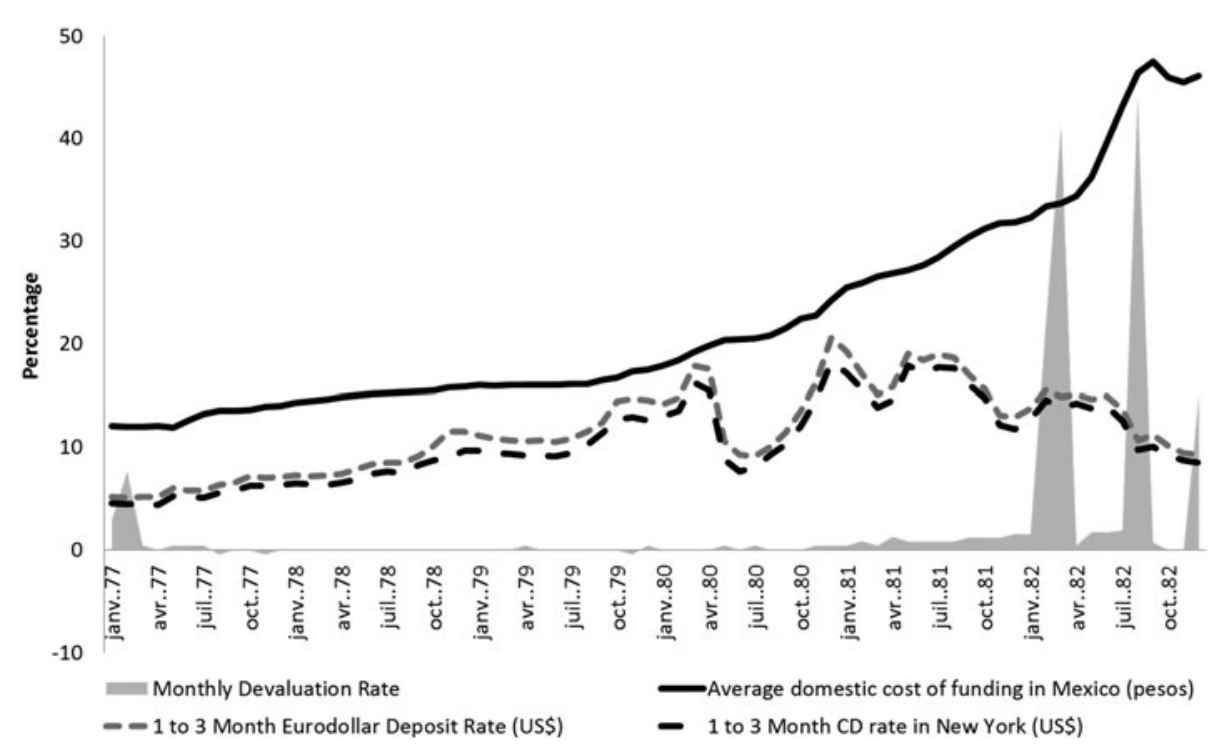

Figure 2. Domestic and international cost of borrowing for Mexican banks, 1977-82

Source: Banco de Mexico's historical statistics.

Through their foreign agencies, commercial banks found the international interbank markets to be new, low-cost funding opportunities. Figure 2 shows the evolution of the average domestic cost of funding compared to interbank interest rates in the US and London, as well as the monthly depreciation of the peso-dollar nominal exchange rate during the I977-82 period. International interest rates were significantly below domestic levels throughout the entire period. This means that, given a virtually fixed exchange rate, it was cheaper for commercial banks to borrow dollars abroad than to raise pesos in Mexico. In fact, between 1977 and I980, the cost of funding in London and New York was, on average, between 40 and 60 per cent lower than in Mexico; a difference that would eventually become even greater as the spread between domestic and international interest rates increased in subsequent years. Additionally, the fact that foreign branches or agencies were not subject to reserve requirements either in Mexico or in host countries further reduced the relative cost of foreign borrowing. ${ }^{27}$

At a microeconomic level, the rationale behind international activities by the commercial banks relied on interest rate arbitrage operations in domestic and foreign markets' yield. As financial historian Carlos Marichal explains, the banks' 'purpose consisted in obtaining cheap funds overseas to lend domestically at higher rates,

27 Since I April I977, the reserve requirement for multipurpose banks was set at the uniform rate of $37.5 \%$ for liabilities in the national currency. In the case of dollar-denominated liabilities held in Mexico, reserve requirements ranged from 70 to I00\% during some years. 
ergo recycling them locally'. ${ }^{28}$ With inflation and interest rates at double-digit levels whilst the peso-dollar nominal exchange rate held practically fixed from I977 until early 1982, the potential for financial gains were significant. As Diaz-Alejandro (I985) observed in the case of Chile, the slow convergence (even divergence) of inflation and interest rates toward international levels, plus the fixed permanent nominal exchange rate, also yielded great incentives for private capital inflows into Mexico and its leading domestic banks were important intermediaries.

\section{IV}

Mexican banks' foreign agencies, which made up the working base of their international businesses, operated under asset-liability imbalances that would prove to be very serious in the run-up to the crisis. Although no complete and systematic information exists about the banks' overseas branches or agencies in Mexican banking and financial statistics, the FFIEC 002 Report of Assets and Liabilities of US Branches and Agencies of Foreign Banks provides balance sheets for those operating in the United States. US agencies accounted for IO of the 2I foreign branches and agencies of Mexican commercial banks, or an estimated of 40 per cent of their total combined assets and liabilities. Given that agencies in London and elsewhere followed a similar business model; the financial position of the US agencies gives a representative sense of the general trend.

Table I shows the cross-border, maturity and interest rate balance sheet composition for Mexican agencies in the US as of June I982. A first worrisome complication could be found in cross-border currency mismatches. The international business model of commercial banks, as previously developed, led to a concentration of their foreign agencies' liabilities within the financial centre where they operated and of their assets abroad. Columns 2 to 4 show the general pattern. While average obligations to creditors domiciled in the US accounted for 67.6 per cent of US agencies' total liabilities, 73.3 per cent of their claims were due to clients domiciled outside the United States, mostly in Mexico. Loans were made in dollars, but to borrowers operating mainly in pesos and not necessarily to exporting firms. Therefore, despite the fact that banks were not currency mismatched in their cross-border operations, their borrowers were. They were consequentially exposed to currency risk and to the balance sheet effects associated with an eventual devaluation of the Mexican peso, as described by Krugman (I999).

A second mismatch involved the maturity composition of the agencies' assets and liabilities. Their heavy reliance on interbank funding came with a liability structure that was almost necessarily biased toward very short-term debts, normally between overnight and six month. As of June I982, up to 27.6 per cent of agencies' total combined liabilities consisted of borrowings (federal and borrowed funds) dues within a day and I9.I were deposits and credit balances for 30 days ending with call date

${ }^{28}$ Marichal (201 I, p. I I9). 
Table 1. Asset and liability structure of US agencies and branches of Mexican banks, June 1982

\begin{tabular}{|c|c|c|c|c|c|c|c|c|c|c|c|}
\hline \multirow{3}{*}{$\begin{array}{l}\text { In millions of } \\
\text { US\$ }\end{array}$} & \multirow{3}{*}{$\begin{array}{c}\text { Total } \\
\text { asset \& } \\
\text { liability }\end{array}$} & \multicolumn{4}{|c|}{ Cross-border currency } & \multicolumn{4}{|c|}{ Maturity } & \multirow{2}{*}{\multicolumn{2}{|c|}{$\begin{array}{c}\text { Interest rate } \\
\begin{array}{c}\text { Com. \& ind. } \\
\text { loans }\end{array}\end{array}$}} \\
\hline & & \multicolumn{2}{|c|}{ US addressees } & \multicolumn{2}{|c|}{$\begin{array}{l}\text { Non-US } \\
\text { addresses }\end{array}$} & \multicolumn{2}{|c|}{ Loans due } & \multirow[b]{2}{*}{$\begin{array}{l}\text { Borrowings } \\
\text { due in a day* }\end{array}$} & \multirow[b]{2}{*}{$\begin{array}{l}\text { TD \& CB for } \\
30 \text { days } \star \star\end{array}$} & & \\
\hline & & Asset & Liability & Asset & Liability & $\begin{array}{l}\text { Within } \\
\text { I year }\end{array}$ & $\begin{array}{l}\text { Over } \\
\text { a year }\end{array}$ & & & $\begin{array}{l}\text { Fixed } \\
\text { rate }\end{array}$ & $\begin{array}{c}\text { Floating } \\
\text { rate }\end{array}$ \\
\hline Bancomer & $\mathrm{I}, 385$ & 366 & 975 & I,OI9 & $4 \mathrm{IO}$ & 554 & I 34 & $36 \mathrm{I}$ & 350 & 393 & 295 \\
\hline Banamex & 74I & 170 & 362 & 572 & 380 & I98 & 64 & I36 & I7 & $26 \mathrm{I}$ & 0 \\
\hline Multibanco Comermex & $42 \mathrm{I}$ & I 29 & $34 \mathrm{I}$ & 292 & 80 & I 54 & 97 & I99 & $7 \mathrm{I}$ & I 30 & I 2 I \\
\hline Banca Serfin & $26 \mathrm{I}$ & 88 & 206 & I 74 & 56 & 98 & 57 & 58 & 69 & I 55 & $\mathrm{o}$ \\
\hline Banco Internacional & I06 & 26 & 89 & 80 & I7 & 22 & $3 \mathrm{I}$ & 50 & 52 & 53 & $\mathrm{o}$ \\
\hline Banco Somex & I & I & o & $\mathrm{o}$ & I & o & o & o & o & o & $\mathrm{o}$ \\
\hline Total US agencies & 2,915 & 779 & $\mathrm{I}, 972$ & $2, \mathrm{I} 36$ & 943 & $\mathrm{I}, \mathrm{O} 26$ & 382 & 804 & 558 & 992 & $4 \mathrm{I} 6$ \\
\hline
\end{tabular}

Notes: ${ }^{*}$ Federal funds and borrowed funds of immediately available funds with one-day maturity.

$\star \star$ Total deposits and credit balances for 30 days (month) ending with call date.

Source: FFIEC 002 Reports. 
(see Table I). Internal computations by the FRBNY staff estimated that around US\$ I. 8 billion would mature between late August and the end of I982, an amount representing almost two-thirds of their total liabilities. ${ }^{29}$ Conversely, the loans that these short-term instruments funded had been extended at much longer maturities. According to information from the FFIEC 002 reports, 73 per cent of the commercial and industrial loans, which were the major component of US agencies assets, were due within the following year and the remaining 27 per cent had a maturity of over one year (see Table I). As will be developed in further detail, the agencies' maturity imbalances would become even worse with the breakup of the crisis.

Agencies also incurred interest rate mismanagement on their borrowing and lending activities. At that time, interbank placements or credit lines were typically arranged at LIBOR plus a modest premium, which would depend on the risk associated with the borrowing bank, meaning that virtually all agencies' debts were contracted at a variable interest rate. In contrast, an important part of the agencies' loan portfolio consisted of claims arranged at predetermined or fixed interest rates. Table I shows that only US\$4 I6 million or 30 per cent of the commercial and industrial loans granted by US agencies had a floating interest rate, while the remaining US $\$$ 992 million or 70 per cent had been arranged at fixed rates. In this context, the sharp increase in international interest rates of the late seventies and early eighties would seriously damage the financial positions of these agencies. While their obligations and debt repayments increased along with the rise in interest rates, only a minor portion of the loan portfolio (which was their main source of revenue) could adjust upward and benefit from the higher rates.

By the time of Mexico's default, foreign agencies had become important extensions of their parent banks and their financial fragility was a latent threat for them as well as the banking system as a whole. A Centro de Información y Estudios Nacionales (CIEN) report estimates that total liabilities of the foreign agencies and branches of the six Mexican international banks reached approximately US $\$ 7.64$ billion in August 1982, an amount accounting for as much as one-fourth of their parent banks' total liabilities and 20 per cent of the banking sector's total liabilities. On the assets side, foreign agencies' credits represented over 50 per cent of the total loan portfolio of commercial banks in Mexico. The exposure of parent banks to their foreign agencies and the large share of these banks in the commercial banking sector made the domestic banking system vulnerable to the risks behind these international operations. ${ }^{30}$

29 Mexican agencies outside the US seem to fit the same pattern. In addition to the US\$ I.8 billion in the US, Mexican agencies outside the US had dollar liabilities of US $\$ 4$ billion maturing between August and the end of December I982, representing altogether approximately $75 \%$ of overseas agencies' total liabilities. See FRBNY Archives, Central Files, file C26 I - Mexican Government I9I7-84.

30 In studying the Thai financial crisis of 1997 and the maturity and currency mismatches of the banking sector with regards to the foreign sector, Allen et al. (2002, pp. 50-9) found that up to one-fourth of the commercial banks' total liabilities were foreign currency denominated, of which $60 \%$ fell due in 
Even more striking is the extent that Mexican banks' foreign agencies impacted the risks faced by the domestic banking system. In a context of economic and financial liberalization, banks are usually confronted with novel forms of risk that can enhance market failures and risk mismanagement already present in the banking sector. Large inflows of foreign capital into a newly liberalized domestic banking sector might further aggravate these problems. In the absence of an appropriate supervisory and regulatory framework, an increase in the availability of loanable funds for domestic financial institutions is likely to raise credit, liquidity and settlement risks; eventually leading to greater systemic risk in the banking sector (McKinnon and Pill I998).

Between I977 and I982, as Mexican banks expanded their international footprint, their funding possibilities and lending capacities significantly increased. During this period, dollar-denominated loans were the most active component of commercial banks' lending, as previously mentioned, and the private sector was the largest recipient of these funds, accounting for 50 per cent of banks' dollar claims as of early 1982. ${ }^{31}$ In fact, the increment of Mexico's private sector external debt during the late I970s relied, to a large extent, on the foreign activities of the commercial banking sector. Given that Mexican international banks belonged to conglomerates which also held the companies that were borrowing the most from abroad, it is likely that these firms were the main beneficiaries of the dollar loans provided by those banks. According to Gutierrez (I992, p. 853), between I979 and I98 I, up to two-thirds of private sector foreign indebtedness came from Mexican commercial banks.

The rise of commercial banks' international financial intermediation came at the expense of higher risks to the banking sector. Table 2 shows the evolution of capital and reserves, cash and non-performing (troubled) assets relative to total assets for the commercial banking sector between 1978 and June I982, directly prior to Mexico's default. In finance theory, the first two values, the leverage ratio and the ratio of (riskless) cash to assets, are considered determinants of the default risk of a bank and are commonly used in the literature as measures of bank risktaking. ${ }^{32}$ They displayed a deterioration in the health of the banking systems: both leverage and cash to total asset ratios were strongly reduced throughout the period. As for troubled assets, it seems only to start to rise as a proportion of total bank assets after the February-March 1982 devaluation. This ratio provides an ex post measure of the riskiness of the assets of a banking sector that have significantly increased the share of dollar loans in their lending portfolio (relative to those denominated in local currency), as discussed above.

the short term, which they state is enormous. The mismatches of the Mexican foreign agencies and their share of the domestic banking sector's total liabilities look similar to these figures, if not worse.

31 As for the remaining, $26.4 \%$ corresponded to the Mexican public sector and $23.6 \%$ to foreign borrowers.

32 See, for instance, Calomiris and Carlson (2014). 
Table 2. Riskiness indicators for commercial banks, percentages

\begin{tabular}{|c|c|c|c|c|c|c|c|c|c|}
\hline & \multicolumn{3}{|c|}{ Leverage ratio ${ }^{\star}$} & \multicolumn{3}{|c|}{ Cash / total assets } & \multicolumn{3}{|c|}{$\begin{array}{c}\text { Troubled assets / } \\
\text { total assets }\end{array}$} \\
\hline & $\begin{array}{c}\text { Dec- } \\
78\end{array}$ & $\begin{array}{c}\text { Dec- } \\
8 \mathrm{I}\end{array}$ & $\begin{array}{l}\text { Jun- } \\
82\end{array}$ & $\begin{array}{c}\text { Dec- } \\
78\end{array}$ & $\begin{array}{c}\text { Dec- } \\
8 \mathrm{I}\end{array}$ & $\begin{array}{c}\text { Jun- } \\
82\end{array}$ & $\begin{array}{c}\text { Dec- } \\
78\end{array}$ & $\begin{array}{c}\text { Dec- } \\
8 \mathrm{I}\end{array}$ & $\begin{array}{r}\text { Jun- } \\
82\end{array}$ \\
\hline International banks & 2.6 & I. 8 & I. 5 & 6.3 & 4.2 & $3 \cdot 5$ & I. 8 & I. 6 & 2.I \\
\hline Bancomer & 2.5 & 2.0 & 2.0 & $7 \cdot 3$ & $4 \cdot 3$ & 2.9 & I.9 & I. 5 & 2.I \\
\hline Banamex & 3.0 & $2 . \mathrm{I}$ & I.6 & 5.1 & 4.9 & 4.6 & 1.5 & I.6 & I.9 \\
\hline Banca Serfin & 2.0 & I. 5 & I.6 & I0.6 & 3.0 & 2.9 & $2 . I$ & I.3 & I. 8 \\
\hline Multibanco Comermex & I.9 & I. 4 & 0.8 & 4.9 & $3 \cdot 7$ & $3 \cdot 3$ & 2.2 & I. 8 & 2.8 \\
\hline Banca Somex & 2.9 & I.4 & 0.9 & I. 5 & 2.5 & I. 7 & І. 8 & I.9 & 2.9 \\
\hline Banco Internacional & 2.6 & 2.0 & I. 2 & 5.0 & $7 \cdot 7$ & $5 \cdot 3$ & I. 3 & I.9 & I. 4 \\
\hline Local banks & 3.0 & 2.2 & 2.0 & 4.8 & 3.8 & 3.8 & I. 6 & I. 8 & 3.0 \\
\hline Total & 2.7 & I.9 & I.6 & 5.9 & $4 \cdot I$ & $3 \cdot 5$ & I. 8 & I.7 & 2.3 \\
\hline
\end{tabular}

$\star$ Computed as the ratio of equity and reserves to total assets.

Source: Comisión Nacional Bancaria y de Seguros.

Indeed, risk taking seems to have been higher in the case of banks involved in international ventures. As of the early I980s, the group of international banks showed greater levels of leverage and lower cash ratios than the banks operating solely on a domestic level. Moreover, the percentage reduction in the ratios is larger in international banks than in local banks, which would suggest that the former were much more aggressive in terms of risk taking than the latter. By participating in international capital markets, these banks received more funds and increased their liabilities without necessarily adding more capital. Figure 3 makes clear the extent to which banks leveraged on foreign funding and increased dollar lending without proportional increments in their capital base. In fact, while lending in pesos relative to capital stands at about I6, the dollar loan portfolio doubled in terms of banks' total capital between I977 and I982 before the devaluation of the peso.

An abundant amount of literature has analysed the factors accounting for international creditor banks' high risk-taking during the I970s Euromarket lending boom to developing countries. While excess liquidity and poor regulation have been highlighted as major problems, scholars have also argued that creditor governments and IMF financial support to countries in payment difficulties might have deterred banks from properly assessing the risks behind these loans (Edwards I986; Folkerts-Landau I985). No conclusive evidence has been found, however, that points to moral hazard or banks' poor lending decisions, in terms of the quantity or the pricing of the bonds and syndicated loans. At a national level, although there are no records on the direct cross-border loans that Mexican domestic commercial 


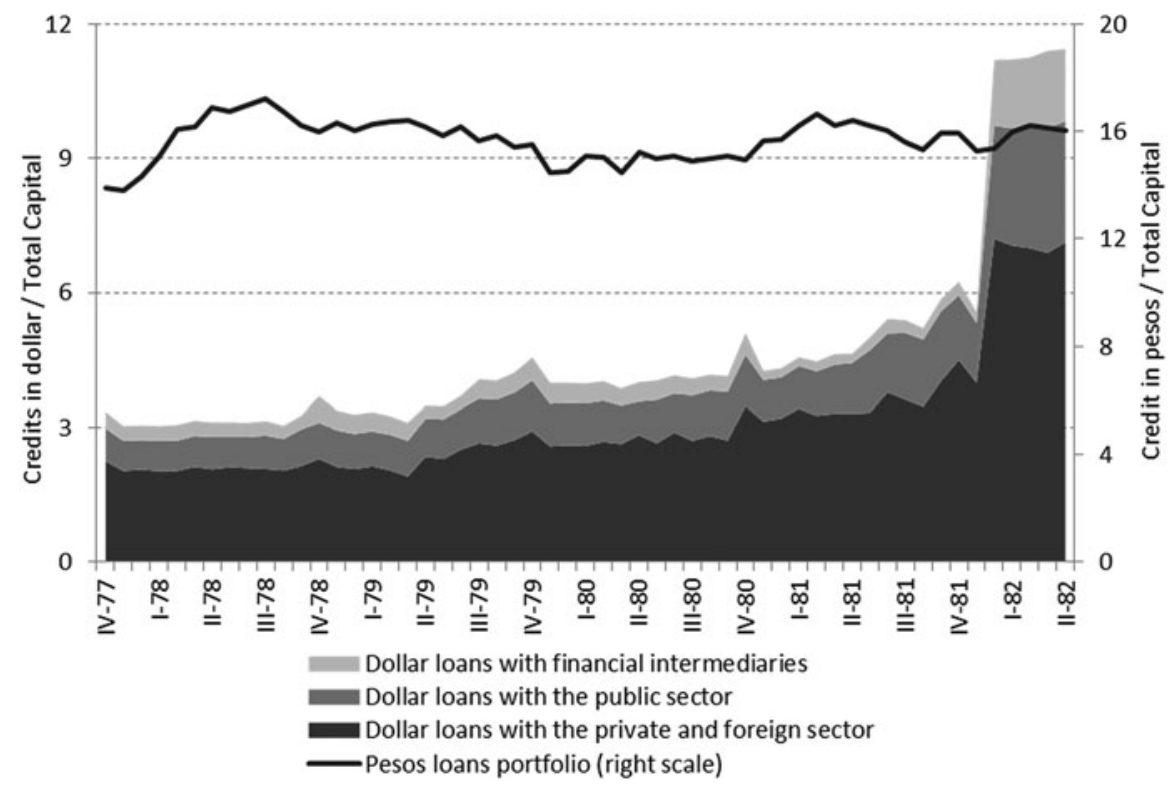

Figure 3. Evolution of the loan portfolio of commercial banks relative to capital, 1977-82

Source: Banco de Mexico's Historical Statistics

banks granted to local borrowers, a number of elements may suggest that the presence of moral hazard most likely encouraged too much dollar lending.

In the first place, the long-standing pegged exchange rate prior to the 1982 crisis could have actually introduced a source of moral hazard among private banks. As argued by Eichengreen and Hausmann (1999), low volatility in exchange rates may have led private investors to believe that authorities implicitly insured them against exchange risk, which in addition to a financial safety net, can cause a large amount of foreign capital inflows to be intermediated through the banking system. In fact, as previously discussed, the Mexican commercial banking system strongly increased their international network, foreign borrowing and lending activities starting in I977 up until the outbreak of the crisis in 1982.

Secondly, commercial bank lending to public development banks also points to the existence of moral hazard stemming from implicit guarantees. Between I970 and I979, as much as 44.6 per cent of syndicated loans to Mexico, with the participation of Mexican banks, went to public financial institutions (Quijano I987, pp. 246-7). Intermex and the Libra Bank, followed by Bancomer, were the main creditors, providing up to 84.3 per cent of the financing. In terms of their Euroloan portfolio, development banks accounted for 47, 87 and 30 per cent of the banks' claims in Mexico respectively. Indeed, the fact that Intermex was jointly owned by Banamex, along with state-owned Nacional Financiera (Nafinsa), Mexico's biggest development bank, and Banco Nacional de Comercio Exterior underscores the 
close ties in international lending between Mexican private banking and the public sector. ${ }^{33}$ Furthermore, board members and counsellors at commercial banks usually held managerial positions in public development banks, as well as in the Mexican government, the Banco de Mexico and other official agencies. ${ }^{34}$

On 20 August 1982, the Mexican government announced a temporary debt moratorium on principal payments that brought the country into default and launched the international debt crisis of the I980s. Although frequently overlooked, the Mexican private sector was also confronting serious debt payment difficulties at the same time. The Alfa Industrial Group, Mexico's main economic conglomerate and the largest private international debtor, suspended principal payments of its foreign debt even before the sovereign debt crisis broke. ${ }^{35}$ Similar to other major economic groups and private companies borrowing abroad, such as the Visa Group, the rise in worldwide interest rates from the previous years, paired with the peso devaluations of early I982, increased the burden of their dollar debt and forced them to eventually go into default and debt restructuring. ${ }^{36}$

The increase in private and public sector external debt repayment problems would have serious repercussions on the domestic banking system. As previously noted, with half of their dollar loan portfolio in the hands of Mexican private companies and an additional quarter owed by the government and public agencies, Mexico's leading international banks and the commercial banking system were highly exposed to financial difficulties. Figure 3 shows the significant extent to which the banking sector was exposed to the risk of debt-servicing difficulties from both the private and public sector when the prospects of devaluation loomed. As a matter of fact, dollar claims passed from representing six times the capital base of the banking sector in the early I982, to more than I t times after the February devaluation. The situation

33 Nafinsa and Banco Nacional de Comercio Exterior bought into Intermex in I978 buying I $3 \%$ of the shares each. For a description of development banking in Mexico and of the international activities of Nafinsa at that time, see Ramírez (i986).

34 For instance, Manuel Espinosa Yglesias, President of Bancomer, had also been a Board Member at Banco de Mexico since I977; Prudencio López Martínez, Alternate Member at Bancomer, was also an Alternate Member at Banco de of Mexico and Nafinsa as well as General Director of Consejo Nacional de Fomento Educativo (Conafe); Finally, Bernardo Quintaja Arrioja, President of the ICA Group, was also a Regional Counselor of Banamex and had served as a member of the management board of Banco de Mexico since I977 (CIEN-Ai3/E-68/Agosto de I982, pp. 22-3).

35 In trouble since late I98 I, when 2,000 highly ranked executives were laid off and some of the company's assets were put up for sale, on 2 I April I982, the group would inform its international creditors that it could no longer pay the principal on its US\$2.3 billion foreign debt. See 'Mexico's Alfa tightens belt', New York Times, 2 I October I98 I and 'The debt burden on Alfa of Mexico', New York Times, io May I982.

36 See Gutierrez (I986). 


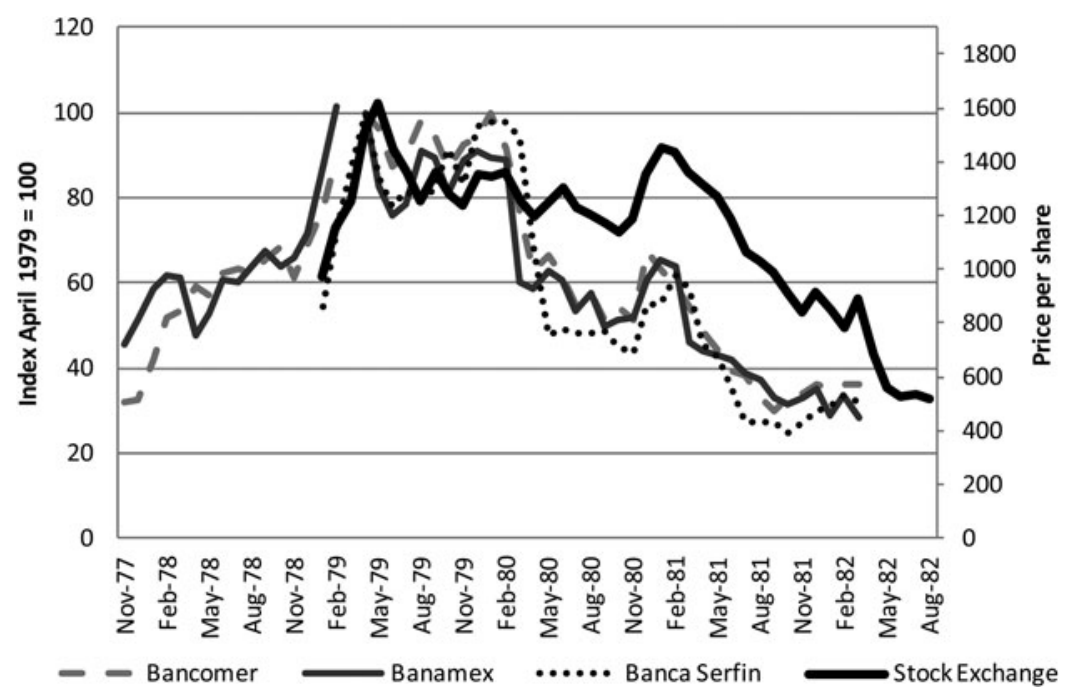

Figure 4. Monthly share prices for international banks and Mexican stock exchange, 1977-82 Source: Anuario Financiero y Bursátil (several issues).

could only get worse during the second half of I982, with the government moratorium, new defaults in the private sector and further devaluations of the peso.

As evident in Figure 4, the market perceived troubles in major international banks well before the Mexican government and private sector defaulted. After a period of dizzying rates of expansion, the rise of Mexican Stock Exchange stopped in 1979 and stagnated for the next two years, before finally busting in I98I. ${ }^{37}$ During the late I970s and early I980s, Bancomer's, Banamex's and Banca Serfin's share prices coincided with the general trend observed in the stock market. However, in the spring of I980 - one year before the bust of the stock market - the share prices of these large international banks collapsed. By June I980, in just six months, banks' stock prices had plummeted to almost half their January value. From there on, banks' share prices continued a downward trend until August I982. The State took the stocks out of the market after the I September I982 nationalization. ${ }^{38}$

At the international level, there were also early signs of Mexican banking fragility. Previous research has shown that the use of borrowed fund from other banks - in the form of interbank certificate of deposits, due bills and rediscounts - is a forecast of

37 For the role of the Mexican stock exchange in the national economy and its relation to the commercial banking system during those years see Quijano (I987, pp. I82-99).

38 Curiously, in late I98 I and early I982, when Bancomer stock prices were at $35 \%$ of their January I 980 value, under the mandate of Bancomer President Manuel Espinosa Yglesias, an offer was made to Citibank and to Bank of America to buy a majority of the shares and take control of the bank. The offer was finally declined (Carral 20I0, pp. I28-30). 


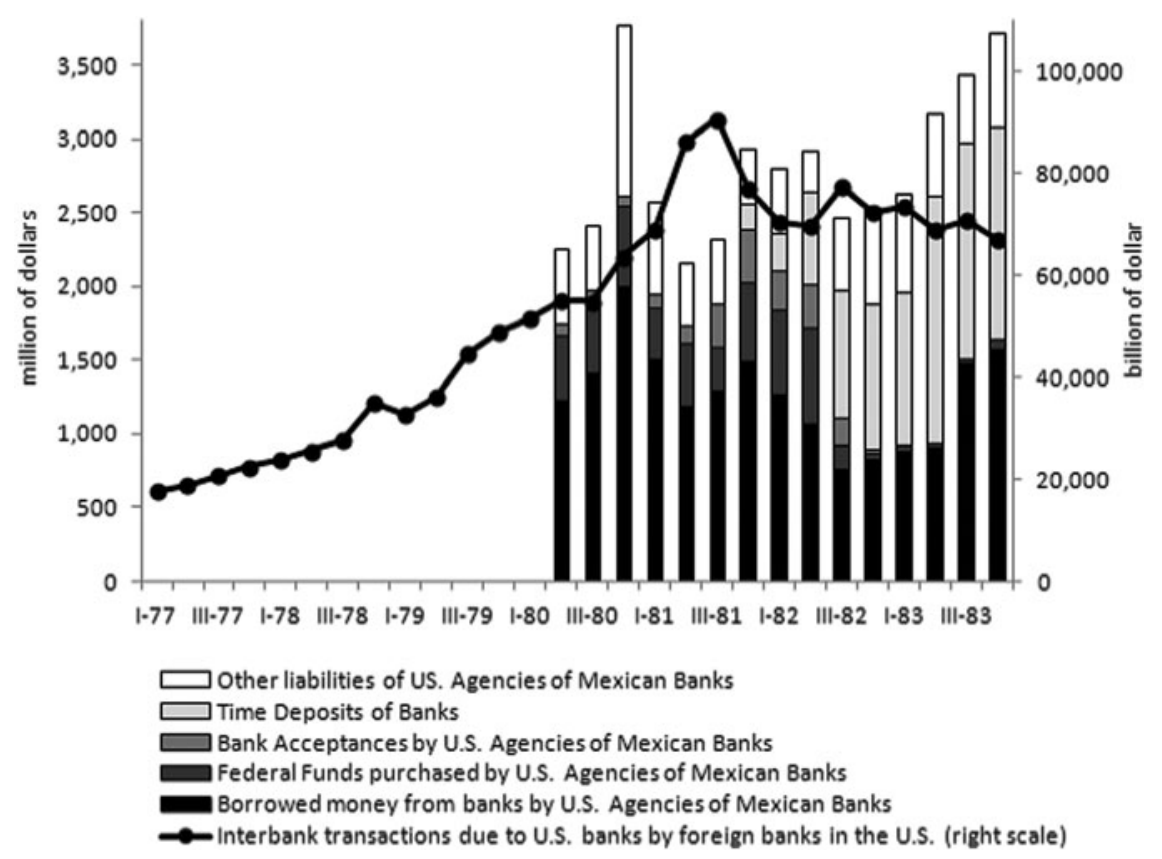

Figure 5. Interbank transactions of foreign banking offices in the US

Source: US Financial Account and FFIEC 002 Reports.

bank distress and can thus be considered a forward-looking risk measurement (Calomiris and Carlson 2014; Calomiris and Mason I997; White I984). ${ }^{39}$ Since these borrowed funds are not low-cost interbank lines, but short-term higher-interest funding or 'hot debt', bank recourse to this source of funds suggests greater level of risk. Figure I shows how much the US agencies of Mexican funding relied on borrowed money as of mid I982, a funding pattern that is confirmed by the past FFIEC 002 reports that those same agencies filed. Overall, from June I 980 to June I982, borrowed funds had an average share of 48 and 50.8 per cent on Bancomer's and Banamex's total liabilities and as much as 57.4 and 60.3 per cent in Multibanco Comermex and Banca Serfin respectively, with peaks ranging from 70 to 84 per cent in some periods. It was, indeed, their most important source of funding during the period.

Mexican banks' agencies in the US would encounter fundraising difficulties as the overall perception of country risk increased. More generally, as observed in Figure 5, September I98 I marked a turning point for the operations of foreign banks in the US

39 Calomiris and Mason (I997, p. 874) observed that during the I920s and I930s, examiners of the Comptroller of the Currency used reliance on borrowed money as a clear indicator of banks having troubles. 
interbank market. After years of solid, rapid growth, foreign banking interbank liabilities due to US banks fell in the fourth quarter of I98 I, again in early I982, and then stagnated. This meant that US commercial banks, which were net providers of funding in the interbank market, not only failed to place any new interbank funds with foreign banks as a group, but also stopped renewing past credit lines and even withdrew deposits from them. However, whether the US interbank credit crunch distressed the funding position of Mexican agencies, the final blow to their money market funding activities came with the onset of the debt crisis in August I982. Figure 5 shows that during I982, borrowed money liabilities fell progressively, until September, when they dropped to half the value they had held as late as the previous December. Federal Funds and banks acceptances, which were the agencies' second major source of funding, would virtually disappear among agencies' liabilities by the end of I 982 .

In this context, it did not take long for Mexican agencies, engaged in term transformation in their international businesses, to face grave liquidity problems when the debt crisis broke out. Deprived of their single most important source of immediate liquidity, interbank liabilities fell due more rapidly than mature assets became available. Lacking alternative funding sources, the agencies' financial position was seriously compromised. These agencies were not FDIC insured and were unable to access the Federal Reserve's discount window facilities. Financial assistance from Mexico would also prove to be limited. At the time, Banco de Mexico was running out of foreign reserves and parent banks were experiencing difficulties in the reimbursement of dollar claims, so home country financial institutions could not offer a definitive solution to US agencies' dollar liquidity needs. After all, Mexican foreign agencies had been working as instruments of their head offices to raise dollars abroad and this arrangement could not work the other way around.

Agencies made up the shortfall in conventional funding by increasing recourse to time deposits from correspondent banks. In this respect, FFEIC 002 reports exhibit a change in the fundraising structure of Mexican agencies from 1982 (see Figure 5). While in I980 and I98I, total deposits and credit balances accounted for, on average Io per cent of agencies' liabilities, by the end of I982, they reached US\$ I.008 billion. In I983, total deposits and credit balances reached US\$ I.46 billion, an amount that was up to 40 per cent of their total liabilities. Virtually all of these funds (over 98 per cent) consisted of timed deposits with six-day terms - mainly in the form of open-account - with developed countries' banks in the US or in foreign countries. FRBNY's internal documents and memorandums stress that Mexican agencies' representatives had been struggling to arrange credit lines with corresponding banks in the US and Europe to ensure the availability of needed funds and avoid liquidity strains. ${ }^{40}$

40 FRBNY Archives, Central Files, file C26I - Mexican Government I9I7-84. Although there is no evidence on how the banks attracted these monies, it is possible that they offered depositors higher interest rates. Banamex New York agency's officials declared that by September I984 'Mexican 
The interbank market upheaval occurred both in the US and also on a broader international level. As demonstrated by the BIS (I983), the international interbank market was truly integrated, with substantial volumes of transactions between banks in the same centre, as well as cross-border transactions. Banks from developing countries also participated, whether located in major financial centres or in their home country. The policy of major banks from industrial countries placing and lending in the international interbank market was based on the creditworthiness of the borrower, which relied on a country risk analysis that looked at the nationality and location of the bank. Under this policy in such an integrated, international market, the BIS reported 'it might be, for example, that the market comes to regard all banks of a certain nationality (e.g. Mexican) with some suspicion, perceiving the interbank operations with them more risky and therefore want to reduce their involvement with them'. ${ }^{41}$

Indeed, an interbank run on Mexican banks would finally break out on Tuesday, 7 September I982. Boughton (200I, p. 30I) reports that during that Black Tuesday, a panic began in the international wholesale markets and international banks refused to roll over lines of credit to Mexican banks on a massive scale. During that same day, officials of the Fed, the FRBNY and the Bank of England worked the telephones to persuade banks to maintain the level of interbank credits with them. He notes that a substantial part of a recently approved BIS bridge loan was used to repay some portion of outstanding claims and that the banks agreed to preserve the rest, thereby succeeding in stabilizing the market without a default. From that point on, as addressed below, Mexican banks could only access the international interbank market and meet liquidity needs because of maintenance commitments that were part of Mexico's debt rescheduling and stand-by agreements. ${ }^{42}$

\section{I}

From the outbreak of the debt crisis in 1982 to the launching of the Brady plan in I989, Mexico went through multiple reschedulings of its external debt. In total, there were four renegotiation rounds: each round led to a corresponding restructuring agreement between Mexico and its international creditors. The principles and the strategy underlying these agreements essentially consisted in rescheduling the existing debt and extending new lending facilities which were conditioned on the agreement to an IMF adjustment programme. ${ }^{43}$ A device associating new bank finance, IMF

banks continue[d] to pay roughly $3 / 4$ of $\mathrm{I} \%$ over LIBOR on their interbank deposits'. See FRBNY Archives, box I42529, file Mexico.

41 BIS Archives, box I/3A(3)M vol. I.

${ }^{42} \mathrm{Kraft}$ (1984, pp. 25-7) provides second-hand evidence on the serious difficulties foreign agencies of Mexican banks were going through in the interbank markets after the moratorium declaration.

43 In total, there were four renegotiation rounds: $1982-3$, I983-4, I984-5 and I986-7. See Negrete Cárdenas (forthcoming) for a description of the debt renegotiation process during this period. 
finance, and other government or multilateral finance was established by creditors to cover Mexico's financial needs. The arrangements reached between Mexico and its creditors aimed to conserve the country's much needed foreign exchange and allow Mexican banks to preserve their dollar funding base.

During debt renegotiations, Mexican banks' interbank funding was an issue of major concern. With their medium- and long-term assets being restructured along with the country's other external debts, the banks' solvency position was under serious threat. Banks were forced to confront increasing difficulties in the renewal of short-term interbank credit lines that had been used to fund these loans. In fact, after the moratorium declaration, the Mexican government and the central bank stepped in to support banks in financial difficulties. Mexico's Public Credit Director and leading negotiator Angel Gurría expressed his serious concerns in a conversation with FRBNY officials about the critical financial position of the US and London branches of Mexican banks. Gurría recounted that he had met with I 40 bankers in Mexico City that day. He stated that he "would point out as emphatically as he could that no bank had ever been allowed to fail in Mexico, ${ }^{44}$ and that the government and the Banco de of Mexico stood strongly behind the banks'. ${ }^{45}$

Despite their willingness, Mexican authorities lacked the financing required to assist the dollar funding needs of its banking sector. ${ }^{46}$ In such a context, as pointed out by Gurría himself, the understanding and cooperation of creditor banks was crucial. He therefore urged then 'not to create a problem by drawing down credit lines'. ${ }^{47}$ Mexico's position was targeted for having international commercial banks keeping open funding lines and preventing interbank credit retrenchment and deposit withdrawals with Mexican banks' foreign agencies. In fact, unlike the bulk of the country's public external obligations, the Mexican government remained current on interbank foreign debt payments even after the moratorium declaration. ${ }^{48}$ By not defaulting or rescheduling this debt, they expected that the interbank market

${ }^{44}$ Up to that point, there had not been a bank failure since 1937.

45 FRBNY Archives, Central Files, file C26I - Mexican Government I9I7-84. A few days after this talk, on I Sept. I982, the Mexican government nationalized the commercial banks, in what scholars have suggested could have been a mechanism to rescue a banking system on the brink of collapse (del Angel 2002, p. 229; Marichal 20I I, p. I22). In this vein, Gurría stated that, although perhaps done for the wrong political reasons, the takeover was a way to solve the financial difficulties of banks that would otherwise have had to declare themselves insolvent. Source: Interview held on 9 July 2013.

${ }^{46}$ During the previously mentioned conversation, Gurría made clear to FRBNY officials that neither the Mexican government nor the Banco de Mexico could deal with the banks' dollar needs on its own because, as he expressed it, '[they were] a little short of cash'. See FRBNY Archive, Central Files, file C26I - Mexican Government I9I7-84.

47 Ibid.

48 With the I Sept. I982 nationalization, private commercial banks' foreign liabilities (as well as their assets) became the responsibility of the Mexican government. Other facilities that were excluded from the restructuring scheme and serviced when due were international organizations' credits, bonds, private placements, leases, bankers' acceptances and trade credits. See FBRNY Archives, Central File, file BAC i982, and also Gurría (1988, p. 77). 
would stay open and creditor banks would renew outstanding placement and provide new credit facilities to the banks.

The interbank issue was also important for Mexico's official creditors. In the US, several interviews were arranged by FRBNY officials with Mexican bankers and government authorities to discuss the situation of the US offices of the Mexican banks. The goal was to assess the real financial position of these agencies and discuss how to deal with their dollar liquidity needs. ${ }^{49}$ As for the IMF, the interbank element was not only necessary to secure the domestic banking system but also, more generally, to implement Mexico's stabilization programme. In fact, Fund officials underlined that international commercial banks' roll-over operations could not be limited to medium- and long-term debt but also needed to integrate 'the interbank element related to the euro-market operations of agency banks, which attract short-term euro-market deposits to re-lend to banks in their own countries at longer maturities'. ${ }^{50}$ In Jacques de Larosière's words, 'it could undermine the rest of the rescheduling operation if the base of the iceberg (the large interbank element) were to dissolve'. ${ }^{51}$

A compromise was eventually reached as part of the first rescheduling agreement. To ensure that the country's foreign bank agencies did not experience a large-scale leakage of funding, outstanding interbank loans were frozen at the August I982 pre-moratorium level. On one hand, with the implementation of the Mexican stabilization programme providing the basis for an IMF money facility for Mexico, creditor banks responded to Mexico's request and agreed to 'maintain current exposure to foreign branches and agencies of Mexican banks, concurring in de Larosière's assessment that it was critical that all banks continue to do so'. ${ }^{2}$ On the other hand, Mexico committed to making sufficient funds available to such agencies and branches to process market interest payments on their interbank account. In the end, with the restructuring loan documentation, creditor banks committed to not letting deposits fall below US $\$ 5.2$ billion until the end of I986. In practice, interbank commitment agreements to keep deposits rolling over 90 days were renewed and then renewed again, whenever they were about to expire.

The US\$ 5.2 billion threshold commitment on interbank outstanding debt to Mexican banks' foreign agencies was to be maintained for ten years. Arguing that Mexican banks needed the interbank placements as a long-term source of funding for their loans to Mexico governed by the restructure agreements, Mexican government officials asked for an extension of the covenant on two occasions. With the I986-7 Financing Packages, the expiration date was extended to June I989 and

\footnotetext{
49 Several documents and internal reports were prepared by the staff of the FRBNY regarding how to proceed in the case of default by an agency. See FRBNY Archives, Central Files, file C26 I Mexico Banco de Mexico I980-2, and C26I - Mexican Government I9I7-84.

50 IMF Archives, OMDF Jacques de Larosière's chronological files, box 3, file 4.

51 Ibid.

52 FBRNY Archive, Central File, file BAC I982.
} 
then again as part of the 1982-89 Financing Package of the Brady Plan, which set the final expiration date on 3 I December I992. The final market-oriented solution came in I99I and consisted in exchanging the interbank deposits for a new instrument, the Floating Rate Privatization Note, which was a direct obligation of the United Mexican States and could be used to purchase shares of Mexican commercial banks under re-privatization.

\section{VII}

Based on this analysis, a number of conclusions can be drawn that both shed new light on the I982 Mexican crisis and also have wider implications for the Latin American and international debt crisis of the I980s. It is revealing that in the years preceding the country's default, leading domestic banks became heavily involved in the international financial system and relied, to a large extent, on foreign interbank borrowing to fund their dollar loans.

A major finding of this study is that in running their international businesses, Mexican bank's foreign agencies accumulated significant maturity and interest rate imbalances. By the time of the crisis, although many of their foreign liabilities consisted of very short-term interbank deposits, the bulk of their dollar denominated assets had much longer maturities. Furthermore, while these interbank credit lines had been set at floating rates, a significant part of the loans was arranged at predetermined fixed rates. Additionally, while balance sheets did not register currency mismatches - their dollar liabilities were from foreigner debtors and their dollar claims were mainly with Mexican debtors running their businesses largely in pesos - they were still indirectly exposed to the risk of an eventual currency crisis.

Important questions remain: how could Mexican banks have possibly increased their risk position to such dangerous levels? Who was responsible? Although beyond the scope of this study, it is difficult to believe that such evident and clumsy mismanagement would have gone unnoticed by financial regulators and by the country's most seasoned bankers. The reasons why banks engaged in foreign lending and took such risky positions in such a tenuous environment must go well beyond their individual initiative and, perhaps, be part of broader scheme that included the government, as well as the public and non-banking private sectors, in a time of great need for financing. The crucial question of the interplay between domestic banks and policymakers in the international banking setting and external indebtedness during the I970s has not yet been addressed in the literature and deserves further investigation.

A final issue that this study raises is with respect to our understanding of the international debt crisis of the I980s. The existing literature, in overlooking the involvement of domestic banks in the petrodollar recycling process of the I970s, has implicitly assumed that debtor countries' banking sectors did not play an important part in the making of the crisis. However, there is no reason to think that my story about Mexican banks represents a pattern that is exclusive to this example. On the 
contrary, banking institutions from other large Latin American borrowers, such as Brazil and Argentina, were also considerably engaged with foreign finance through a similar business model. Therefore, in considering the participation of commercial banks from borrowing countries in international capital markets, a main implication is that the origins of the debt crisis should be revised and reconsidered.

The fact that interbank deposits from foreign banks with the overseas agencies and branches of Mexican commercial banks had to be frozen at pre-moratorium levels for almost ten years is a clear sign of their financial weakness and critical dependence on foreign finance. Similar interbank arrangements were also undertaken during debt renegotiations and rescheduling agreements in Brazil and Argentina. This finding suggests that further work still needs to be done to understand the link between sovereign and domestic banks during the Latin American debt crisis of the I980s. As can be currently observed in many peripheral European countries, banks' heavy reliance on foreign interbank funding has not only played a crucial role in explaining the vulnerability of their banking sectors, but in the sovereign debt crisis as well. In turn, difficulties faced by governments have put further pressure on banks' foreign interbank funding possibilities, exacerbating banking and sovereign debt problems.

Submitted: 27 August 20I4

Revised version submitted: i9 February 2015

Accepted: io March 2015

First published online: 21 April 2015

\section{Sources}

Bank for International Settlements' Archives: Box I/3A(3)M vol. I (Basle)

Euromoney (London: several issues)

Federal Reserve Bank of New York's Archives: Box I08403, Box I42529, and Central Files - Files: BAC I982, BAC I983, C261 Mexico - Banco de Mexico I980-I982, C26I - Mexican Government I9I7-I984 (New York)

Informe Anual del Banco de México (Mexico, D.F.: I977-I982).

International Monetary Fund's Archives: OMDF Jacques de Larosière's chronological files, Box 3 (Washington DC)

The Banker (London: several issues)

New York Times (New York: several issues)

\section{References}

ALLEN, M., ROSENBERG, C., KELLER, C., SETSER, B. and ROUBINI, N. (2002). A balance sheet approach to financial crisis. IMF Working Paper, WP/02/2 Io.

ALTIMIR, O. and DEVLIN, R. (I994). Moratoria de la deuda en América Latina. Mexico, DF: Fondo de Cultura Económica.

DEL ANGEL, G. (2002). Paradoxes of Financial Development: The Construction of the Mexican Banking System. 1941-1982. Stanford: Stanford University Press.

DEL ANGEL, G. (2006). The corporate governance of the Mexican banking system: a historical perspective, I940-2000. CIDE, Documento de trabajo no. 373.

BÉRTOLA, L. and OCAMPO, J. (2012). The Economic Development of Latin America Since Independence. London: Oxford University Press.

BIS (1983). The International Interbank Market: A Descriptive Study. Basle, Switzerland. 
BORJA MARTÍNEZ, F. (1978). Desarrollo del derecho bancario mexicano (I968-I977). In Jurídica: Anuario Del Departamento de Derecho de La Universidad Iberoamericana, vol. I. Mexico, DF: Universidad Iberoamericana.

BOUGHTON, J. (200I). Silent Revolution: The International Monetary Fund, 1979-1989. Washington, DC: International Monetary Fund.

CALOMIRIS, C. and MASON, J. (I997). Contagion and bank failures during the Great Depression: the June 1932 Chicago banking panic. American Economic Review, 87(5), pp. 863-83.

CALOMIRIS, C. and CARLSON, M. (20I4). Corporate governance and risk management at unprotected banks: national banks in the I 890s. NBER Working Paper Series, no. I9806.

CARRAL, J. (20I0). La banca extranjera y la estatización de la banca. In A. Espinosa Rugarcía and E. Cárdenas Sánchez (eds.), La nacionalización bancaria, 25 años después, vol. II. Mexico, DF: Centro de Estudios Espinosa Yglesias.

CARUANA, J. and VAN RIXTEL, A. (2OI3). International financial markets and bank funding in the euro area: dynamics and participants. BIS Research paper.

CLINE, W. (1984). International Debt: Systemic Risk and Policy Response. Washington, DC: Institute for International Economics.

CLINE, W. (1995). International Debt Reexamined. Washington, DC: Institute for International Economics.

Committee on the Global Financial System (2010). The functioning and resilience of cross-border funding markets. CGFS Papers, no. 37.

Committee on the Global Financial System (20 I I). The impact of sovereign credit risk on bank funding conditions. CGFS Papers, no. 43.

DAVIS, S. (1980). The Euro-Bank: Its Origins, Management and Outlook. New York: John Wiley and Sons.

DEVLIN, R. (1989). Debt and Crisis in Latin America: The Supply Side of the Story. Princeton: Princeton University Press.

DEVLIN, R. and FFRENCH-DAVIS, R. (1995). The great Latin America debt crisis: a decade of asymmetric adjustment. Revista de Economica Politica, I5(3), pp. I I 7-42.

DIAZ-ALEJANDRO, C. (I984). Latin American debt: I don't think we are in Kansas anymore. Brookings Papers on Economic Activity, I5(2), pp. 335-403.

DIAZ-ALEJANDRO, C. (I985). Good-bye financial repression, hello financial crash. Journal of Development Economics, I9, pp. I-24.

DORNBUSCH, R. (I990). Mexican debt. In D. Brothers and A. Wick (eds.), Mexico's Search for a New Development Strategy. Boulder, CO: Westview Press.

DUFEY, G. and GIDDY, I. (1994). The International Money Market. Englewood Cliffs, NJ: Prentice Hall.

EDWARDS, S. (1986). The pricing of bonds and bank loans in international markets: an empirical analysis of developing countries' foreign borrowing. European Economic Review, 30(3), pp. 565-89.

EICHENGREEN, B. and HAUSMANN, R. (1999). Exchange rates and financial fragility. NBER Working Paper Series, no. 7418.

FENDER, I. and MCGUIRE, P. (20I0). European banks' US dollar funding pressures. BIS Quarterly Review, June, pp. 57-64.

FOLKERTS-LANDAU, D. (1985). The changing role of international bank lending in development finance. Staff Papers - International Monetary Fund, 32(2), pp. 317-63.

GREEN, R. (I988). La deuda externa de México, 1973-1987: de la abundancia a la escasez de créditos. Mexico, DF: Editorial Nueva Imagen.

GREEN, R. (1998). Lecciones de la deuda externa de México, de 1973 a 1997: de abundancias y escaseces. México, DF: Fondo de Cultura Económica.

GURRÍA, J. (1988). Debt restructuring: Mexico as a case study. In S. Griffith-Jones (ed.), Managing World Debt. New York: St Martin's Press.

GUTIERREZ, R. (1986). El endeudamiento del sector privado de México: expansión y negociación. Comercio exterior, 36(4), pp. 337-43.

GUTIERREZ, R. (I992). El endeudamiento externo del sector privado de Mexico, I97I-I99I. Comercio exterior, $\mathbf{4 2}(9)$, pp. $852-64$.

HONOHAN, P., DONOVAN, D., GORECKI, P. and MOTTIAR, R. (20I0). The Irish banking crisis: regulatory and financial stability policy 2003-2008. MPRA Paper no. 24896, pp. I-I 84 . 
KAMINSKY, G. and SCHMUKLER, S. (2003). Short-run pain, long-run gain: the effects of financial liberalization. IMF Working Paper, WP/03/34.

KRAFT, J. (1984). The Mexican Rescue. New York: Group of Thirty.

KRUGMAN, P. (I999). Balance sheets, the transfer problem, and financial crises. In P. Isard, A. Razin and A. Rose (eds.), International Finance and Financial Crises: Essays in Honor of Robert P. Flood. Boston: Kluwer Academic Publishers.

MARICHAL, C. (2000). Deuda externa y política en México, I946-2000. In I. Bizberg and L. Meyer (eds.), México al filo del siglo XXI: cambio y resistencia. Mexico, DF: Océano.

MARICHAL, C. (2OI I). Crisis de deudas soberanas en México: empresas estatales, bancos y relaciones internacionales, I970-I990. Historia y Política, 26, pp. I I I-33.

MCKINNON, R. and PILL, H. (1998). International overborrowing: a decomposition of credit and currency risks. World Development, 26(7), pp. I267-82.

MENDOZA, E. and TERRONES, M. (2008). An anatomy of credit booms: evidence from macro aggregates and micro data. NBER Working Paper Series, no. I 4049.

MENTRE, P. (1985). The international interbank market and international bank lending. FRBNY Archives, box I08403.

MERK MARTEL, M., VAN RIXTEL, A. and GONZALEZ MOTA, E. (2OI2). Business models of international banks in the wake of the 2007-2009 global financial crisis. Banco de España Revista de Estabilidad Financiera, 22, pp. 99-I2 I.

NEGRETE CÁRDENAS, S. (I999). Mexican debt crises: a new approach to their genesis and resolution. MS, University of Essex.

NEGRETE CÁRDENAS, S. (forthcoming). Debt and Crises in Mexico. Mexico, DF: Centro de Estudios Espinosa Yglesias.

QUIJANO, J. (1987). México: Estado y Banca Privada. Mexico, DF: CIDE.

RAMÍREZ, M. (1986). Development Banking in Mexico: The Case of the Nacional Financiera, S.A. New York: Praeger.

SACHS, J. and WILLIAMSON, J. (1985). External debt and macroeconomic performance in Latin America and East Asia. Brookings Papers on Economic Activity, 2, pp. 523-73.

SÁNCHEZ AGUILAR, E. (I973). The international activities of US commercial banks: a case study: Mexico. MS, Harvard University.

SEIJAS ROMÁN, G. (I99I). Políticas y estrategias de la banca múltiple. Mexico, DF: Colegio de México.

SHAMBAUGH, J. (2012). The euro's three crises. Brookings Papers on Economic Activity, Spring, pp. I $57-2$ I I.

SOLÍS, L. (1997). Evolución del sistema financiero mexicano hacia los umbrales del siglo XXI. Mexico, DF: Siglo XXI.

SOLÍS, L. and ZEDILLO, E. (I985). The foreign debt of Mexico. In G. Smith and J. Cuddington (eds.), International Debt and the Developing Countries. Washington, DC: The World Bank.

Special Investigation Commission (2010). Causes of the Collapse of the Icelandic Banks - Responsibility, Mistakes and Negligence.

SUNDARARAJAN, V. and BALIÑO, T. (I99I). Banking Crises: Cases and Issues. Washington, DC: International Monetary Fund.

VAN RIXTEL, A. and GASPERINI, G. 20I3. Financial crises and bank funding: recent experience in the euro area. BIS Working Papers, no. 406.

WELLONS, P. (1977). Borrowing by Developing Countries on the Euro-Currency Market. Paris: OECD.

WHITE, E. (I984). A reinterpretation of the banking crisis of I93O. Journal of Economic History, 44(I), pp. II $9-38$.

ZEDILLO, E. (1985). The Mexican external debt : the last decade. In M. Wionczek and L. Tomassini (eds.), Politics and Economics of External Debt Crisis: The Latin American Experience. Boulder, CO: Westview Press. 